\title{
Effects of Abattoir Waste on the Surface Water Quality of Dei-Dei River, Abuja, Nigeria
}

\author{
Jibrin Ahmadu ${ }^{1}$, Ogechukwu Franca Eze ${ }^{1}$, Ofigo Kesiena ${ }^{2}$, Bessie Hanis ${ }^{3}$, Fidelis Micheal ${ }^{4}$ \\ ${ }^{1}$ Department of Pollution Control and Environmental Health, Federal Ministry of Environment, Abuja, Nigeria \\ ${ }^{2}$ Infantini Systems Consult LTD. Abuja, Nigeria \\ ${ }^{3}$ National Biotechnology Development Agency, Abuja, Nigeria \\ ${ }^{4}$ Universal Basic Education, Abuja, Nigeria
}

Email address:

jigbane2@gmail.com (J. Ahmadu), francaking.o@gmail.com (O. F. Eze), ofigokesiena@gmail.com (O. Kesiena), bessiehanis@gmail.com (B. Hanis),mail4fidel@yahoo.com (F. Micheal)

\section{To cite this article:}

Jibrin Ahmadu, Ogechukwu Franca Eze, Ofigo Kesiena, Bessie Hanis, Fidelis Micheal. Effects of Abattoir Waste on the Surface Water Quality of Dei-Dei River, Abuja, Nigeria. International Journal of Environmental Chemistry. Vol. 4, No. 2, 2020, pp. 38-45.

doi: $10.11648 /$ j.ijec.20200402.11

Received: January 31, 2020; Accepted: April 1, 2020; Published: August 31, 2020

\begin{abstract}
This study has investigated the Effects of Abattoir Waste on the Surface Water Quality of Dei-Dei River, Abuja. It assessed the impacts of abattoir waste disposal on Dei-Dei River, biological properties such as E-coli, Faecal Streptococci, Total Coliform Count (TCC) and Cryptosporidium Oocyst (Co), with results compared with WHO standards. Field methods included consultation with Health and Water Quality Expert, collection of water samples at varying distance and laboratory analysis of water samples using standard techniques. The analysis at the upstream, revealed that at point 1 , E.coli was $2.00 \mathrm{cfu} / \mathrm{ml}$ above 0 $\mathrm{cfu} / \mathrm{ml}$ and TCC was $18 \mathrm{cfu} / \mathrm{ml}$ above $10 \mathrm{cfu} / \mathrm{ml}$ benchmark for raw water respectively. At Point 2, E.Coli was $1.00 \mathrm{cfu} / \mathrm{ml} \mathrm{above} 0$ $\mathrm{cfu} / \mathrm{ml}$ while TCC is $12.00 \mathrm{cfu} / \mathrm{ml}$. At Point 3, E. Coli was $1.00 \mathrm{cfu} / \mathrm{ml}$ above $0 \mathrm{cfu} / \mathrm{ml}$ while TCC is $20.00 \mathrm{cfu} / \mathrm{ml}$ and above the bench mark for raw water. The midstream of the study area, revealed that at Point 1 , E.coli was $3.00 \mathrm{cfu} / \mathrm{ml} \mathrm{above} 0 \mathrm{cfu} / \mathrm{ml} \mathrm{and}$ TCC was $25 \mathrm{cfu} / \mathrm{ml}$ above $10 \mathrm{cfu} / \mathrm{ml}$ benchmark for raw water respectively. At Point 2, E.Coli was $2.00-\mathrm{cfu} / \mathrm{ml} \mathrm{above} 0 \mathrm{cfu} / \mathrm{ml}$ while TCC is $22.00 \mathrm{cfu} / \mathrm{m}$, Co $1 \log$ reduction 1 . At Point 3, E. Coli was $1.00 \mathrm{cfu} / \mathrm{ml} \mathrm{above} 0 \mathrm{cfu} / \mathrm{ml} \mathrm{while} \mathrm{TCC} \mathrm{is} 9.00 \mathrm{cfu} / \mathrm{ml}$. The result of the analysis of sample collected at the downstream of the study area revealed that at Point 1 , E.coli was $5.00 \mathrm{cfu} / \mathrm{ml}$ above $0 \mathrm{cfu} / \mathrm{ml}$ and TCC was 32cfu/ml above $10 \mathrm{cfu} / \mathrm{ml}$, Co $2 \log$ reduction and within the benchmark for raw water respectively. At Point 2, E.Coli was $3.00 \mathrm{cfu} / \mathrm{ml}$ above $0 \mathrm{cfu} / \mathrm{ml}$ while TCC is $38.00 \mathrm{cfu} / \mathrm{ml}$, Co1 log reduction and within the Benchmark for raw water respectively. At Point 3, E. Coli was $1.00 \mathrm{cfu} / \mathrm{ml}$ above $0 \mathrm{cfu} / \mathrm{ml}$ while TCC is $35.00 \mathrm{cfu} / \mathrm{ml}$ and Co $0.00 \mathrm{log}$ reduction and within the benchmark for raw water respectively, while at Point 1 and Point 2, E.Coli and TCC were above the bench mark for raw water. Presence of these micro-biological components are indications that the surface water of the study area may likely be responsible for diseases such as typhoid fever, diarrhoea and cholera if used for drinking purpose. The study has also made recommendations to address the problems revealed such as; improvement of sanitation of the study area, provision of adequate waste management facilities while sensitization of the people is given priority, ensuring clean water in the area and efforts to stop dumping of Abattoir waste into the river and at the river bank.
\end{abstract}

Keywords: Effects, Abattoir Waste, Surface Water, Quality, Dei-Dei River, Abuja

\section{Introduction}

The disposal of wastewater, washing of roasted animals after slaughter, disposal of animal parts with body fluids has caused immense environmental problems not only to the aquatic environment but also to human beings. This problem started long back but intensified during the last few decades, and now the situation has become alarming in Nigeria [1]. In the study of a natural ecosystem, many variables simultaneously change with time and location with little opportunity to control them all, systematically or otherwise. By measuring as many parameters as possible that defines the system, Trop. Freshwat. Biol. 0795- 
0101/01/\$08.50@2011 Idodo Umeh Publishers Ltd., Nigeria 92 F. E. [2]. It may be possible to understand their interactions and to assess the sustainability of the environment [3, 4] Industrial activities and urbanization in developing countries including Nigeria has gradually led to the deterioration and contamination of the natural environment in recent years.

Generally, increased awareness on environmental issues can be attributed to an increasing realization of the dangers posed to human life and various ecological segments by unabated degradation of our basic environments due to man's quest for development. One major concern is the effect of anthropogenic activities on the aesthetics, economic viability, safety and health. Economic losses attributable to environmental degradation include the damage to vegetation and crops and the subsequent effect on the livestock. Effluent from the abattoir could pose major environmental and health problem to the aquatic systems. The long and short term safety and health effect on humans and livestock depend upon the physical and chemical characteristics of the pollutant and exposure to such polluted water system. Several authors have reported that the Nigerian Environment has deteriorated tremendously [5] and the most adverse effect is concentrated around the environment of the Niger Delta [6]. Increased demand for slaughtered livestock has led to a growing concern over the indiscriminate disposal of abattoir (slaughter house) wastes in surface water bodies in urban centres located along river systems. This practice has hitherto continued unchecked. The Dei-Dei River is non-tidal freshwater ecological system located in Bwari Area Council, Abuja, FCT, Nigeria. The river is a tributary of Ushafa river and it is being used for domestic purposes and as a source of drinking water to some communities along its bank. The perceptible activities of economic value in the area are subsistence fishing, slaughter of animals (abattoir) and commercial sand exploitation. The river is influenced by human activities going on, which if not properly managed can pose severe health risk to the populace. Literature on the water quality of this river is sparse; therefore a systematic study on the river water quality is of great necessity and significance.

\subsection{Research Questions}

The following research questions were posed in order to facilitate the investigation.

i. What is the quality of the surface water of Dei-Dei River in Abuja?

ii. What is the effect of Abattoir waste on the surface water quality of Dei-Dei River in Abuja?

iii. Is the surface water of Dei-Dei River suitable for human consumption?

\subsection{Aim and Objectives}

The aim of this study was to assess the effect of abattoir waste disposal on Dei-Dei River in Abuja. The specific objectives are: i. Determine the surface water quality consequent upon Abattoir waste disposal on Dei-Dei River in Abuja;

ii. Assessing the effect of Abattoir waste on the surface water quality of Dei-Dei River in Abuja;

iii. Determine the suitability of the surface water of DeiDei River for human consumption.

\subsection{Scope of the Study}

This research has spatial and contextual scope. In terms of the spatial scope, the study was restricted to Dei-Dei River. On the contextual scope, the research was limited to the study of water quality in Dei-Dei River. The study did not cover other sources of pollution in the study area such as air and noise Pollution.

\section{Concept of Solid Wastes and Water Pollution}

Solid waste is generated from industrial, residential and commercial activities in a given area. In Simple term, Solid wastes are any discarded or abandoned materials that may be solid, liquid, and semi-solid or containerized gaseous material. Waste can be categorized based on its contents, including such materials as plastic, paper, glass, metal, and organic waste. Categorization may also be based on hazard potential, including radioactive, flammable, infectious, toxic, or non-toxic. The menace posed by Municipal solid waste, particularly in the urban areas is one of the gravest environmental challenges facing the world, Nigeria for instance. The problem is exacerbated by urban migration, overpopulation, emergency of urban slums, industrialization, changes in consumption patterns, inadequate planning, lack of resources and facilities to sustainably manage the waste that are being generated. Solid waste management in Nigeria is characterized by inefficient collection methods, insufficient coverage of the collection system and improper disposal. Disposal in most Nigerian cities include, co-disposal of hazardous including hospital wastes with Municipal waste in open, unlined dumpsites, open burning of municipal solid wastes, dumping on water bodies and in other unauthorized place with attendant environmental and health consequences.

Water pollution is a major global problem which requires on-going evaluation and revision of water resource policy at all levels (international down to individual aquifers and wells). It has been suggested that water pollution is the leading worldwide cause of deaths and diseases and that it accounts for the deaths of more than 14,000 people daily. Water pollution almost, always means that some damage has been done to an ocean, river, lake, or other water source. "The introduction by man, directly or indirectly, of substances or energy into the marine environment (including estuaries) resulting in such deleterious effects as harm to living resources, hazards to human health, hindrance to marine activities, including fishing, impairment of quality for use of sea water and reduction of amenities." - [7].

Thus, water pollution is all about quantities: how much of 
a polluting substance is released and how big a volume of water it is released into. Virtually any human activity can have an effect on the quality of our water environment. When farmers fertilize the fields, the chemicals they use are gradually washed by rain into the groundwater or surface waters nearby. Also according to [8], wastes dumped at the river bank is primarily responsible for the contamination of the river considering the heap of waste present which could result to slopes, allowing easy runoff into the river. Sometimes the causes of water pollution are quite surprising. Chemicals released by smokestacks (chimneys) can enter the atmosphere and then fall back to earth as rain, entering seas, rivers, and lakes and causing water pollution. The pollution of water in which human and other organisms depend on invariably can cause socioeconomic challenges ranging from poverty and joblessness to involuntary displacement [9]. There are also two different ways in which pollution can occur; if pollution comes from a single location, such as a discharge pipe attached to a factory, it is known as pointsource pollution. But when the water polluted is not from one single source but from many different scattered sources, it is called nonpoint-source pollution.

The awareness on water pollution due to waste disposal is high among the communities that live within the catchment as their educational level is good. However, discharge of gray water as well as black water by people who live close to the canal is evident. Though their awareness on water pollution and possible consequences is high, they still continue to practise these activities due to lack of options for proper disposal of solid and liquid wastes.

\subsection{Biological Characteristics of Wastewater}

The major groups of microorganisms present in wastewater are bacteria, fungi, protozoa, microscopic plants and animals, viruses and helminths [10]. Most microorganisms (bacteria, protozoa) are responsible and also beneficial for biological treatment processes of wastewater $[11,10]$. However, [12] reported that, depending on the dose and susceptibility of the host, some of these organisms found in wastewater can cause diseases of the gastrointestinal tract such as typhoid and paratyphoid fever, dysentery, diarrhoea and cholera. [13] reported that faecal coliforms are the most commonly used indicator bacteria for faecal contamination, since their excreted load is similar or larger than that of pathogenic organisms, and their survival time in the environment is longer.

\subsection{Surface Water Quality Monitoring}

Water quality monitoring, as defined by [14] refers to the actual collection of information at specific locations and at regular intervals in order to provide data, which may be used to define current conditions, establish trends, etc. According to $[15,16]$, water quality monitoring is an essential tool for environmental agencies to determine the quality of water bodies and make management decisions for improving or protecting the intended uses. It is therefore necessary that consistent information on water quality is collected, analysed and evaluated in a timely and efficient manner [15]. To achieve this, authors of various guidelines for surface water monitoring [17]; Tennessee Valley Authority [18] assert that appropriate documentation of data and the use of clean sampling equipment are imperative. [19] also recommends that, the hydrology and morphometric (e.g measurements of volume, depth, etc.) of a stream or impoundment are also important factors to be determined prior to sampling. This will aid in determining the presence of phases or layers in Streams or impoundments, flow patterns in streams, and appropriate sample locations and depths. Although there are no universal sampling procedures due to widely varying sampling situations.

The water samples can be in the form of grab or composite samples depending on the field conditions and study data needs $[18,17]$. A surface grab sample may be necessitated based on the following conditions; stream velocity is such that penetration to depth is not easily obtained, surface sheen/film is identified, low water exists, or a sample from the upper surface of the water body is required [20] But when the sample will be used to describe general water quality bracketing a period of time, a composite sample can be collected using an automated composite sampler.

\section{Research Methodology}

This section has examined the methods used in the collection and analyses of water sample that was required to address the aim and objectives of the study.

\subsection{Reconnaissance Survey}

In carrying out this study, a reconnaissance survey of the study area was carried out to select the appropriate collection points for water sample within the stream.

\subsection{Materials Used for Water Sample Collection}

The basic materials and equipment that were used in carrying out this study are presented thus:

i. One litre of plastic container for each sample

ii. Masking tape

iii. Marker

iv. Writing pad

v. Cooler/Cool box

vi. Ranging Poles

vii. Measuring Tape.

\subsection{Sampling Procedure}

Three sampling point was identified in the study area; an upstream point, that is, 200metres away before the waste dump, the contact point where the waste is dumped and another 200 meters away from the contact point, that is the downstream.

The surface water sample was collected in November, 2019 and the sampling container rinsed with nitric acid. This was to avoid the contamination of the container. After 
collection, nitric acid $(0.2 \%)$ was added as a preservative. The samples marked and labelled after the source of water, sampling location and date of water sample collection. The collected sample was preserved in ice-block containing plastic coolers and transported to the laboratory for analysis. $\mathrm{pH}$ of the water samples was determined in-situ during samples collections.

\subsection{Water Sample Analyses}

Microbiological test was carried out using the following procedures;

i. Weigh an amount of MCA (according to the manufacturer's instruction) in a conical flask and add the required volume of water.

ii. Heat to boil on a hot plate

iii. Allow to cool

iv. Dispense $20 \mathrm{ml}$ into the universal bottle

v. Sterilize at $121^{\circ} \mathrm{C}$ for 15 minutes

vi. Allow to cool at $45^{\circ} \mathrm{C}$

vii. Pour into a sterile to solidify

viii. Streak the MCA with the nutrient broth containing the sample that has been incubated for 24 hours

ix. Invert the petric dish and incubate at $37^{\circ} \mathrm{C}$ for 24 hours

x. Examine for growth on the MCA after 24 hours

xi. Gram staining can be carried out for positive result.

\subsubsection{Determination of Total Coliform Count}

Agar - MacConkey Agar (MCA)

Procedure for preparation of MCA

Formular $=52 \times 20 \times \mathrm{n} / 1000$

$\mathrm{N}=$ number of $\mathrm{ml}$

Procedures;

i. Weigh an amount of MCA (according to the manufacturers instruction) in a conical flask and add the required volume of water

ii. Heat to boil on a hot plate

iii. Allow to cool

iv. Dispense $20 \mathrm{ml}$ into the universal bottle

v. Sterilize at $121^{\circ} \mathrm{C}$ for 15 minutes

vi. Allow to cool at $45^{\circ} \mathrm{C}$

vii. Pour into a sterile to solidify

viii. Streak the MCA with the nutrient broth containing the sample that has been incubated for 24 hours

ix. Invert the petric dish and incubate at $37^{\circ} \mathrm{C}$ for 24 hours

$\mathrm{x}$. Examine for growth on the MCA after 24hours.

\subsubsection{Determination of Cryptosporidium Oocyst}

i. Some quantity of the water sample were collected in test tubes and subjected to centrifugation at 4000rpm for 5-10 minutes; ii. The centrifuged water sample was decanted to remain the residue at the bottom of the test tubes;

iii. The water sample residue was used for microscopic observation, using wet mount technique, by pouring the sample residue on a clean glass-slide then covered with a cover-slip;

iv. The samples were focused using $10 \mathrm{x}$ objectives and then $40 \mathrm{x}$ objectives for proper magnification and contrast to check for the presence of cryptosporidium oocyst by comparing with an atlas.

\subsubsection{Determination of Faecal Streptococci}

Preparation of Blood agar

i. Suspend $28 \mathrm{~g}$ of nutrient agar powder in 1 litre of distilled water.

ii. Heat this mixture while stirring to fully dissolve all components.

iii. Autoclave the dissolved mixture at $121^{\circ} \mathrm{C}$ for 15 minutes.

iv. Once the nutrient agar medium has been autoclaved, allow to cool at $55-50^{\circ} \mathrm{C}$, but not solidify, add $5 \% \mathrm{v} / \mathrm{v}$ sterile defibrinated blood that has been warmed at room temperature and mix gently and avoid air bubbles.

v. Dispense into sterile petri dishes and allow to solidify.

vi. $24 \mathrm{~h}$ culture of the water samples in a nutrient broth was inoculated on the blood agar medium and incubated at $37^{\circ} \mathrm{C}$ for $24 \mathrm{~h}$.

vii. The incubated plates were observed for the absence or gamma haemolysis to suspect for presence of Faecal Streptococci.

viii.Further characterization was done by Grams reaction of the growth.

\subsubsection{Determination of Clostridium Perfringens}

i. Inoculate 24 hours culture of the sample from the nutrient broth on already prepared Anaerobic blood agar

ii. Incubate at $37^{\circ} \mathrm{C}$ for $24-48$ hours

iii. Observe for growth

NB: Clostridium perfringens usually produces a double zone of hemolysis

Further characterization can be done by Grams reaction of the growth.

\subsubsection{Determination of $E$. coli}

Agar - MacConkey Agar (MCA)

Procedure for preparation of MCA

Formular $=52 \times 20 \times \mathrm{n} / 1000$

$\mathrm{N}=$ number of sample to be prepare.

\section{Presentation of Results and Discussion}

\subsection{The Quality of the Surface Water in Dei-Dei River in Abuja}

This Chapter presents the results of field survey, laboratory analysis of water samples collected as well as the presumed 
implication on human health.

Table 1. Microbiological ANALYSIS OF UP-STREAM.

\begin{tabular}{llllll}
\hline S/N & \multirow{2}{*}{ PARAMETERS } & \multirow{2}{*}{ NIS REQUIREMENT } & $\begin{array}{l}\text { RESULT FOR } \\
\text { POINT 1 }\end{array}$ & $\begin{array}{l}\text { RESULT FOR } \\
\text { POINT 2 }\end{array}$ & $\begin{array}{l}\text { RESULT FOR } \\
\text { POINT 3 }\end{array}$ \\
\hline 1 & Clostridium Perfringenes (cfu/ml) & 0 & $0.00 \mathrm{cfu} / \mathrm{ml}$ & $0.00 \mathrm{cfu} / \mathrm{ml}$ & $0.00 \mathrm{cfu} / \mathrm{ml}$ \\
2 & E. coli $(\mathrm{cfu} / \mathrm{ml})$ & 0 & $2.00 \mathrm{cfu} / \mathrm{ml}$ & $1.00 \mathrm{cfu} / \mathrm{ml}$ & $1.00 \mathrm{cfu} / \mathrm{ml}$ \\
3 & Faecal Streptococcus $(\mathrm{cfu} / \mathrm{ml})$ & 0 & $0.00 \mathrm{cfu} / \mathrm{ml}$ & $0.00 \mathrm{cfu} / \mathrm{ml}$ & $0.00 \mathrm{cfu} / \mathrm{ml}$ \\
4 & Total Coliform count $(\mathrm{cfu} / \mathrm{ml})$ & $10 \mathrm{cfu} / \mathrm{mL}$ & $18.00 \mathrm{cfu} / \mathrm{ml}$ & $12.00 \mathrm{cfu} / \mathrm{ml}$ & $20.00 \mathrm{cfu} / \mathrm{ml}$ \\
5 & Cryptosporidium Oocyst & 3log reduction \& or inactivation & $0.00 \log$ reduction & $0.00 \operatorname{log~reduction}$ & $0.00 \log$ reduction \\
\hline
\end{tabular}

Source: Sample Analysis 2019.

Table 2. Microbiological ANALYSIS OF MID-STREAM.

\begin{tabular}{llllll}
\hline \multirow{2}{*}{ S/N } & \multirow{2}{*}{ PARAMETERS } & \multirow{2}{*}{ NIS REQUIREMENT } & $\begin{array}{l}\text { RESULT FOR } \\
\text { POINT 1 }\end{array}$ & $\begin{array}{l}\text { RESULT FOR } \\
\text { POINT 2 }\end{array}$ & $\begin{array}{l}\text { RESULT FOR } \\
\text { POINT 3 }\end{array}$ \\
\hline 1 & Clostridium Perfringenes $(\mathrm{cfu} / \mathrm{ml})$ & 0 & $0.00 \mathrm{cfu} / \mathrm{ml}$ & $0.00 \mathrm{cfu} / \mathrm{ml}$ & $0.00 \mathrm{cfu} / \mathrm{ml}$ \\
2 & E. coli $(\mathrm{cfu} / \mathrm{ml})$ & 0 & $3.00 \mathrm{cfu} / \mathrm{ml}$ & $2.00 \mathrm{cfu} / \mathrm{ml}$ & $1.00 \mathrm{cfu} / \mathrm{ml}$ \\
3 & Faecal Streptococcus $(\mathrm{cfu} / \mathrm{ml})$ & 0 & $0.00 \mathrm{cfu} / \mathrm{ml}$ & $0.00 \mathrm{cfu} / \mathrm{ml}$ & $0.00 \mathrm{cfu} / \mathrm{ml}$ \\
4 & Total Coliform count $(\mathrm{cfu} / \mathrm{ml})$ & $10 \mathrm{cfu} / \mathrm{mL}$ & $25.00 \mathrm{cfu} / \mathrm{ml}$ & $22.00 \mathrm{cfu} / \mathrm{ml}$ & $9.00 \mathrm{cfu} / \mathrm{ml}$ \\
5 & Cryptosporidium oocyst & 3log reduction \& or inactivation & $0.00 \log$ reduction & $1.00 \log$ reduction & $0.00 \mathrm{log} \mathrm{reduction}$ \\
\hline
\end{tabular}

Source: Sample Analysis 2019.

Table 3. Microbiological ANALYSIS OF DOWN-STREAM

\begin{tabular}{llllll}
\hline S/N & PARAMETERS & NIS REQUIREMENT & $\begin{array}{l}\text { RESULT FOR } \\
\text { POINT 1 }\end{array}$ & $\begin{array}{l}\text { RESULT FOR } \\
\text { POINT 2 }\end{array}$ & $\begin{array}{l}\text { RESULT FOR } \\
\text { POINT 3 }\end{array}$ \\
\hline 1 & Clostridium Perfringenes (cfu/ml) & 0 & $0.00 \mathrm{cfu} / \mathrm{ml}$ & $0.00 \mathrm{cfu} / \mathrm{ml}$ & $0.00 \mathrm{cfu} / \mathrm{ml}$ \\
2 & E. coli $(\mathrm{cfu} / \mathrm{ml})$ & 0 & $5.00 \mathrm{cfu} / \mathrm{ml}$ & $3.00 \mathrm{cfu} / \mathrm{ml}$ & $1.00 \mathrm{cfu} / \mathrm{ml}$ \\
3 & Faecal Streptococcus $(\mathrm{cfu} / \mathrm{ml})$ & 0 & $0.00 \mathrm{cfu} / \mathrm{ml}$ & $0.00 \mathrm{cfu} / \mathrm{ml}$ & $0.00 \mathrm{cfu} / \mathrm{ml}$ \\
4 & Total Coliform count $(\mathrm{cfu} / \mathrm{ml})$ & $10 \mathrm{cfu} / \mathrm{mL}$ & $32.00 \mathrm{cfu} / \mathrm{ml}$ & $38.00 \mathrm{cfu} / \mathrm{ml}$ & $35.00 \mathrm{cfu} / \mathrm{ml}$ \\
5 & Cryptosporidium oocyst & 3log reduction \& or inactivation & $2.00 \log \mathrm{reduction}$ & $1.00 \log$ reduction & $0.00 \mathrm{log} \mathrm{reduction}$ \\
\hline
\end{tabular}

Source: Sample Analysis 2019.

\subsection{Effect of Abbatoir Waste on the Surface Water Quality of Dei-dei River in Abuja}

Table 4. Microbiological ANALYSIS OF UP-STREAM.

\begin{tabular}{|c|c|c|c|c|c|}
\hline $\mathbf{S} / \mathbf{N}$ & PARAMETERS & NIS REQUIREMENT & $\begin{array}{l}\text { RESULT FOR } \\
\text { POINT } 1\end{array}$ & $\begin{array}{l}\text { RESULT FOR } \\
\text { POINT } 2\end{array}$ & $\begin{array}{l}\text { RESULT FOR } \\
\text { POINT } 3 \\
\end{array}$ \\
\hline 1 & Clostridium Perfringenes (cfu/ml) & 0 & $0.00 \mathrm{cfu} / \mathrm{ml}$ & $0.00 \mathrm{cfu} / \mathrm{ml}$ & $0.00 \mathrm{cfu} / \mathrm{ml}$ \\
\hline 2 & E. coli $(\mathrm{cfu} / \mathrm{ml})$ & 0 & $2.00 \mathrm{cfu} / \mathrm{ml}$ & $1.00 \mathrm{cfu} / \mathrm{ml}$ & $1.00 \mathrm{cfu} / \mathrm{ml}$ \\
\hline 3 & Faecal Streptococcus (cfu/ml) & 0 & $0.00 \mathrm{cfu} / \mathrm{ml}$ & $0.00 \mathrm{cfu} / \mathrm{ml}$ & $0.00 \mathrm{cfu} / \mathrm{ml}$ \\
\hline 4 & Total Coliform count (cfu/ml) & $10 \mathrm{cfu} / \mathrm{mL}$ & $18.00 \mathrm{cfu} / \mathrm{ml}$ & $12.00 \mathrm{cfu} / \mathrm{ml}$ & $20.00 \mathrm{cfu} / \mathrm{ml}$ \\
\hline 5 & Cryptosporidium oocyst & $3 \log$ reduction $\&$ or inactivation & $0.00 \log$ reduction & $0.00 \log$ reduction & $0.00 \log$ reduction \\
\hline
\end{tabular}

Source: Sample Analysis 2019.

The result of the analysis of sample collected at the up-stream of the study area as shown on table 1 indicates that at point 1 , E. coli was $2.00 \mathrm{cfu} / \mathrm{ml}$ above $0 \mathrm{cfu} / \mathrm{ml}$ and Total Coliform Count was $18 \mathrm{cfu} / \mathrm{ml}$ above $10 \mathrm{cfu} / \mathrm{ml} \mathrm{Benchmark} \mathrm{for} \mathrm{raw} \mathrm{water}$ respectively. At Point 2, E. Coli was $1.00 \mathrm{cfu} / \mathrm{ml}$ above $0 \mathrm{cfu} / \mathrm{ml}$ while Total Coliform Count is $12.00 \mathrm{cfu} / \mathrm{ml}$. At Point 3, E. Coli was $1.00 \mathrm{cfu} / \mathrm{ml}$ above $0 \mathrm{cfu} / \mathrm{ml}$ while Total Coliform Count is $20.00 \mathrm{cfu} / \mathrm{ml}$ and above the bench mark for raw water.

Table 5. Microbiological ANALYSIS OF MID-STREAM.

\begin{tabular}{lllll}
\hline S/N & PARAMETERS & NIS REQUIREMENT & RESULT FOR POINT 1 & $\begin{array}{l}\text { RESULT FOR } \\
\text { POINT 2 }\end{array}$ \\
\hline 1 & Clostridium Perfringenes $(\mathrm{cfu} / \mathrm{ml})$ & 0 & $0.00 \mathrm{cfu} / \mathrm{ml}$ & $0.00 \mathrm{cfu} / \mathrm{ml}$ \\
2 & E. coli $(\mathrm{cfu} / \mathrm{ml})$ & 0 & $3.00 \mathrm{cfu} / \mathrm{ml}$ & $2.00 \mathrm{cfu} / \mathrm{ml}$ \\
3 & Faecal Streptococcus $(\mathrm{cfu} / \mathrm{ml})$ & 0 & $0.00 \mathrm{cfu} / \mathrm{ml}$ & $0.00 \mathrm{cfu} / \mathrm{ml}$ \\
4 & Total Coliform count $(\mathrm{cfu} / \mathrm{ml})$ & $10 \mathrm{cfu} / \mathrm{Ml}$ & $25.00 \mathrm{cfu} / \mathrm{ml}$ & $0.00 \mathrm{cfu} / \mathrm{ml}$ \\
5 & Cryptosporidium oocyst & $\begin{array}{l}\text { 3log reduction } \& \text { or } \\
\text { inactivation }\end{array}$ & $0.00 \log$ reduction & $9.00 \mathrm{cfu} / \mathrm{ml}$ \\
\hline
\end{tabular}

Source: Sample Analysis 2019. 
The result of the analysis of sample collected at the midstream of the study area as shown on table 2 indicates that at Point 1 , E. coli was $3.00 \mathrm{cfu} / \mathrm{ml}$ above $0 \mathrm{cfu} / \mathrm{ml}$ and Total Coliform Count was $25 \mathrm{cfu} / \mathrm{ml}$ above $10 \mathrm{cfu} / \mathrm{ml}$ Benchmark for raw water respectively. At Point 2, E. Coli was 2.00 $\mathrm{cfu} / \mathrm{ml}$ above $0 \mathrm{cfu} / \mathrm{ml}$ while Total Coliform Count is 22.00 $\mathrm{cfu} / \mathrm{m}$, Criptosporidium oocyst $1 \log$ reduction 1 . At Point 3 , E. Coli was $1.00 \mathrm{cfu} / \mathrm{ml}$ above $0 \mathrm{cfu} / \mathrm{ml}$ while Total Coliform Count is $9.00 \mathrm{cfu} / \mathrm{ml}$ and above the bench mark for raw water.

Table 6. Microbiological ANALYSIS OF DOWN-STREAM.

\begin{tabular}{|c|c|c|c|c|c|}
\hline $\mathbf{S} / \mathbf{N}$ & PARAMETERS & NIS REQUIREMENT & $\begin{array}{l}\text { RESULT FOR } \\
\text { POINT } 1\end{array}$ & $\begin{array}{l}\text { RESULT FOR } \\
\text { POINT } 2\end{array}$ & $\begin{array}{l}\text { RESULT FOR } \\
\text { POINT } 3\end{array}$ \\
\hline 1 & Clostridium Perfringenes (cfu/ml) & 0 & $0.00 \mathrm{cfu} / \mathrm{ml}$ & $0.00 \mathrm{cfu} / \mathrm{ml}$ & $0.00 \mathrm{cfu} / \mathrm{ml}$ \\
\hline 2 & E. coli $(\mathrm{cfu} / \mathrm{ml})$ & 0 & $5.00 \mathrm{cfu} / \mathrm{ml}$ & $3.00 \mathrm{cfu} / \mathrm{ml}$ & $1.00 \mathrm{cfu} / \mathrm{ml}$ \\
\hline 4 & Total Coliform count (cfu/ml) & $10 \mathrm{cfu} / \mathrm{mL}$ & $32.00 \mathrm{cfu} / \mathrm{ml}$ & $38.00 \mathrm{cfu} / \mathrm{ml}$ & $35.00 \mathrm{cfu} / \mathrm{ml}$ \\
\hline 5 & Cryptosporidium oocyst & 3log reduction \& or inactivation & $2.00 \log$ reduction & $1.00 \log$ reduction & $0.00 \log$ reduction \\
\hline
\end{tabular}

Source: Sample Analysis 2019.

The result of the analysis of sample collected at the downstream of the study area as shown on table 3 indicates that at Point 1, E. coli was $5.00 \mathrm{cfu} / \mathrm{ml}$ above $0 \mathrm{cfu} / \mathrm{ml}$ and Total Coliform Count was $32 \mathrm{cfu} / \mathrm{ml}$ above $10 \mathrm{cfu} / \mathrm{ml}$, Cryptosporidium oocyst $2 \log$ reduction and within the Benchmark for raw water respectively. At Point 2, E. Coli was $3.00 \mathrm{cfu} / \mathrm{ml}$ above $0 \mathrm{cfu} / \mathrm{ml}$ while Total Coliform Count is $38.00 \mathrm{cfu} / \mathrm{ml}$, Cryptosporidium oocyst $1 \log$ reduction and within the Benchmark for raw water respectively. At Point 3, E. Coli was $1.00 \mathrm{cfu} / \mathrm{ml}$ above $0 \mathrm{cfu} / \mathrm{ml}$ while Total Coliform Count is $35.00 \mathrm{cfu} / \mathrm{ml}$ and Cryptosporidium oocyst $0.00 \mathrm{log}$ reduction and within the Benchmark for raw water respectively, while in Point 1 and Point 2, E. Coli Total Coliform count were above the bench mark for raw water.

\subsection{Suitability of Surface Water of Dei-dei River for Human Consumption}

\subsubsection{Microbiological Analysis of Up-stream}

The result of the analysis of sample collected at the upstream of the study area as shown on table 4 indicates that at Point 1 , E. coli was $2.00 \mathrm{cfu} / \mathrm{ml}$ above $0 \mathrm{cfu} / \mathrm{ml}$ and Total Coliform Count was $18 \mathrm{cfu} / \mathrm{ml}$ above $10 \mathrm{cfu} / \mathrm{ml}$ Benchmark for raw water respectively. At Point 2, E. Coli was 1.00 $\mathrm{cfu} / \mathrm{ml}$ above $0 \mathrm{cfu} / \mathrm{ml}$ while Total coliform

Count is $12.00 \mathrm{cfu} / \mathrm{ml}$. At Point 3, E. Coli was $1.00 \mathrm{cfu} / \mathrm{ml}$ above $0 \mathrm{cfu} / \mathrm{ml}$ while Total Coliform Count is $20.00 \mathrm{cfu} / \mathrm{ml}$ and above the bench mark for raw water. This shows that the surface water of Dei-Dei River in Abuja has high contamination of E. Coli and Total Coliform Count. This makes the water not suitable for human consumption. Consultation with Health Expert indicated that diseases such as Typhoid and cholera may be associated with the consumption of the surface water of Dei-Dei River in Abuja and this may pose danger to human health if it is consumed.

\subsubsection{Microbiological Analysis of Mid-stream}

The result of the analysis of sample collected at the midstream of the study area as shown on table 5 indicates that at Point 1 , E. coli was $3.00 \mathrm{cfu} / \mathrm{ml}$ above $0 \mathrm{cfu} / \mathrm{ml}$ and Total Coliform Count was $25 \mathrm{cfu} / \mathrm{ml}$ above $10 \mathrm{cfu} / \mathrm{ml}$ Benchmark for raw water respectively. At Point 2, E. Coli was 2.00 $\mathrm{cfu} / \mathrm{ml}$ above $0 \mathrm{cfu} / \mathrm{ml}$ while Total Coliform Count is 22.00 $\mathrm{cfu} / \mathrm{m}$, Cryptosporidium oocyst $1 \log$ reduction 1 . At Point 3 , E. Coli was $1.00 \mathrm{cfu} / \mathrm{ml}$ above $0 \mathrm{cfu} / \mathrm{ml}$ while Total Coliform Count is $9.00 \mathrm{cfu} / \mathrm{ml}$ and above the bench mark for raw water.

The result indicates that at a distance of 200meters from the upstream, the water is still not suitable for human consumption and could pose danger to human health. This could also be responsible for diahorea and Typhoid fever if it is consumed.

\subsubsection{Microbiological Analysis of Down-stream}

The result of the analysis of sample collected at the downstream of the study area as shown on table 6 , indicates that water collected at the down-stream of Dei-Dei River, the water is not suitable for human consumption because at Point 1, E. coli was $5.00 \mathrm{cfu} / \mathrm{ml}$ above $0 \mathrm{cfu} / \mathrm{ml}$ and Total Coliform Count was $32 \mathrm{cfu} / \mathrm{ml}$ above $10 \mathrm{cfu} / \mathrm{ml}$, Cryptosporidium oocyst $2 \log$ reduction and within the Benchmark for raw water respectively. At Point 2, E. Coli was $3.00 \mathrm{cfu} / \mathrm{ml}$ above $0 \mathrm{cfu} / \mathrm{ml}$ while Total Coliform Count is $38.00 \mathrm{cfu} / \mathrm{ml}$, Cryptosporidium Oocyst $1 \log$ reduction and within the Benchmark for raw water respectively. At Point 3, E. Coli was $1.00 \mathrm{cfu} / \mathrm{ml}$ above $0 \mathrm{cfu} / \mathrm{ml}$ while Total Coliform Count is $35.00 \mathrm{cfu} / \mathrm{ml}$ and Cryptosporidium Oocyst $0.00 \mathrm{log}$ reduction and within the Benchmark for raw water respectively, while in Point 1 and Point 2, E. Coli Total Coliform count were above the bench mark for raw water. Diseases such as cholera, Diahorea and Typhoid fever are likely to be contacted if the water is consumed as indicated above.

\section{Summary, Conclusion and Recommendation}

\subsection{Summary}

This study was on the effect of Abattoir waste on the surface water quality of Dei-Dei River in Abuja. The study has analysed the quality of the surface water, the effect of abattoir waste on the surface water quality of Dei-Dei River 
and the Suitability of the surface water of Dei-Dei River for human consumption. This study was also able to determine whether the quality (Microbiological) of the surface water of Dei-Dei River were within the WHO acceptable benchmark for domestic use. A comprehensive analysis of the water samples collected at different points within the study area was carried out and reveals the presence of some Microbiological Components. These components were found in the analysis of the surface water from the Up-stream, Midstream and Down-stream of the study area. The result of the analysis of sample collected at the up-stream of the study area as shown on table 1 indicates that at point 1 , E. coli was $2.00 \mathrm{cfu} / \mathrm{ml}$ above $0 \mathrm{cfu} / \mathrm{ml}$ and Total Coliform Count was $18 \mathrm{cfu} / \mathrm{ml}$ above $10 \mathrm{cfu} / \mathrm{ml}$ benchmark for raw water respectively. At Point 2, E. Coli was $1.00 \mathrm{cfu} / \mathrm{ml}$ above 0 $\mathrm{cfu} / \mathrm{ml}$ while Total Coliform Count is $12.00 \mathrm{cfu} / \mathrm{ml}$. At Point 3, E. Coli was $1.00 \mathrm{cfu} / \mathrm{ml}$ above $0 \mathrm{cfu} / \mathrm{ml}$ while Total Coliform Count is $20.00 \mathrm{cfu} / \mathrm{ml}$ and above the bench mark for raw water.

The result of the analysis of sample collected at the midstream of the study area as shown on table 2 indicates that at Point 1 , E. coli was $3.00 \mathrm{cfu} / \mathrm{ml}$ above $0 \mathrm{cfu} / \mathrm{ml}$ and Total Coliform Count was $25 \mathrm{cfu} / \mathrm{ml}$ above $10 \mathrm{cfu} / \mathrm{ml}$ benchmark for raw water respectively. At Point 2, E. Coli was 2.00 $\mathrm{cfu} / \mathrm{ml}$ above $0 \mathrm{cfu} / \mathrm{ml}$ while Total Coliform Count is 22.00 $\mathrm{cfu} / \mathrm{m}$, Cryptosporidium oocyst $1 \log$ reduction 1 . At Point 3, E. Coli was $1.00 \mathrm{cfu} / \mathrm{ml}$ above $0 \mathrm{cfu} / \mathrm{ml}$ while Total Coliform Count is $9.00 \mathrm{cfu} / \mathrm{ml}$ and above the bench mark for raw water.

The result of the analysis of sample collected at the downstream of the study area as shown on table 3 indicates that at point 1 , E. coli was $5.00 \mathrm{cfu} / \mathrm{ml}$ above $0 \mathrm{cfu} / \mathrm{ml}$ and Total Coliform Count was $32 \mathrm{cfu} / \mathrm{ml}$ above $10 \mathrm{cfu} / \mathrm{ml}$, Cryptosporidium oocyst $2 \log$ reduction and within the benchmark for raw water respectively. At Point 2, E. Coli was $3.00 \mathrm{cfu} / \mathrm{ml}$ above $0 \mathrm{cfu} / \mathrm{ml}$ while Total Coliform Count is $38.00 \mathrm{cfu} / \mathrm{ml}$, Cryptosporidium Oocyst $1 \log$ reduction and within the benchmark for raw water respectively. At Point 3, E. Coli was $1.00 \mathrm{cfu} / \mathrm{ml}$ above $0 \mathrm{cfu} / \mathrm{ml}$ while Total Coliform Count is $35.00 \mathrm{cfu} / \mathrm{ml}$ and Cryptosporidium Oocyst $0.00 \mathrm{log}$ reduction and within the benchmark for raw water respectively, while in Point 1 and Point 2, E. Coli Total Coliform count were above the bench mark for raw water.

However, the study has revealed that water collected from these points in the study area is not fit for domestic consumption as it is likely to be accompanied by after effects on human health.

\subsection{Conclusion}

The analysis revealed the quality of surface water in the study area. The result from the samples analysed from the Up-stream, Mid-stream and Down-stream indicated that abattoir waste affect the quality of surface water for domestic use. Human activities at the bank of the river and within the local community have affected the quality of rain water in Dei-Dei River. However, the results obtained from the analysis was compared with [19] required limits for domestic water. The result of analysis obtained has shown that the effect of Abattoir waste has affected the surface water quality of Dei-Dei River and it is not fit for drinking because of the high concentration of E. Coli and Total Coliform Count at different points from the Up-Stream, Mid-Stream and DownStream and which may cause panic if the river water is used for domestic consumption.

\subsection{Recommendation}

Environmental and health hazards posed by human activities along River Dei-Dei can be reduced by adapting best environmental practice. Current Practices along the river bank should be discouraged. Waste collection bins should be used to collect abattoir waste along the river bank and within the rural community of Dei-Dei. Proper waste collection practices should be adopted with recycling options on abattoir waste, to minimize the amount of hazardous material that is being disposed in the river at the study area. Other remedial action maybe required, such as sensitisation and awareness creation, proper waste collection and disposal facilities, enforcement of existing legal framework and provision of recycling facilities to further boost economic growth of the community while establishing modern Abattoir in Dei-Dei.

\section{Acknowledgements}

The authors would like to thank the Staff of the; Department of Pollution Control and Environmental Health of the Federal Ministry of Environment, National Biotechnology Development Agency, Infantini Systems Consult Ltd., Universal Basic Education, Abuja, Nigeria and the Staff at the Department of Environmental Management, Nasarawa State University, Keffi for their immense support and insight during this study.

\section{References}

[1] Arimoro, F. O., Ikomi, R. B. Response of Macroinvertebrate Communities to Abattoir Wastes and other Anthropogenic activities in a municipal stream in the Niger Delta, Nigeria. Environmentalist 28, 85-98 (2008).

[2] Egobueze, F. E, Iwegbue, C. M. A \& Opuene, K. Preliminary Assessment of Heavy metals levels of soils of an oil field in the Niger Delta, Nigeria. Int. J. Environ. Sci. Technol. 3, 167172 (2006).

[3] Hopke, P. K., 1985. Receptor Modelling in Environmental Chemistry. John Wiley, New York.

[4] Jonnalagadda, S. B. and G. Mhere, 2001. Water quality of the Odzi River in the Eastern Highlands of Zimbabwe. Water Res., 35: $2371-2376$.

[5] Olowanda, 1974; 1989; Pickford, 1983 - Effect of abattoir wastes on the water quality of Aleto River in the Niger Delta, Nigeria.

[6] Odu E. A. 1981 Productive Phenology of some Tropical African Mosses. 
[7] UN Report 2012: The United Nations World Water Development; Managing Water under Uncertainty and Risk: Executive summary.

[8] O. F. Eze et. al. (2019): Effects of Solid Waste on the Surface Water Quality of Usuma River, Phase IV, Kubwa - Abuja, Nigeria; International Journal of Environmental Protection and Policy.

[9] N. A Abugu et. al: A Journal of the Department of Environmental Management, Faculty of Environmental Science, Nasarawa State University, Keffi; Vol. 01, No. 01, 2018.

[10] Lee, C. C. (2007). Handbook of Environmental Engineering Calculations. 2nd Edition. McGraw-Hill Professional Publishing, New York.

[11] Liu, D (1999). Environmental Engineers Handbook.

[12] Awuah, E. (2006). Pathogen Removal Mechanisms in Macrophyte and Algal Waste Stabilization Ponds. Doctoral Dissertation, UNESCO-IHE Institute for Water Education. Taylor and Francis Group/Balkema, Rotterdam, the Netherlands.

[13] Strauss, M. (2000). Health (Pathogen) Considerations Regarding the Use of Human Waste in Aquaculture. Swiss Federal Institute for Environmental Science and Technology (EAWAG). Department of Water and Sanitation in Developing Countries (SANDEC). Duebendorf, Switzerland.
[14] UNESCO (2003). Water for People, Water for Life: UN World Water Development Report (WWDR), Paris, United Nations Educational, Scientific and Cultural Organization.

[15] Helmer, R. (1997). Water Quality Monitoring: National and International Approaches. Hydrological, Chemical and Biological Processes of Transformation and Transport of Contaminants in Aquatic Environments. Proceedings of the Rostov-on-Don Symposium, May 1993. IAHS (219).

[16] Abdul-Razak, A., Asiedu A. B., Entsua-Mensah, R. E. M. and de Graft-Johnson, K. A. (2009). Assessment of the Water Quality of the Oti River in Ghana. West African Journal of Applied Ecology, Vol. 15.

[17] USEPA (2007). Surface Water Sampling. Science and Ecosystem Support Division (SESD) Operating Procedure. US-EPA, Region 4, Athens, Georgia Number: SESDPROC201-R1.

[18] Tennessee Valley Authority (2009). Standard Operating Procedure for Surface. The Netherlands.

[19] United States Environmental Protection Agency (USEPA). 1994. Nitrogen Control, Lancaster, USA: Technomic Publishing Company Inc.

[20] WHO (2010): World Water Day, water for Health, WHO Press, World Health Organization, 20 Avenue Appia, 1211 Geneva 27, Switzerland. 